\title{
E-Commerce Adoption by Women Entrepreneurs in India: An Application of the UTAUT Model
}

\author{
Ananya Goswami (Corresponding author) \\ Dept. of Management, Birla Institute of Technology, Mesra, Kolkata Campus \\ Southend Conclave, $4^{\text {th }}$ Floor, 1582 Rajdanga Main Road, Kolkata 700107, India \\ Tel: 91-33-2441-4542Ｅ-mail: pal.ananya@gmail.com
}

\begin{abstract}
Sraboni Dutta
Dept. of Management, Birla Institute of Technology, Mesra, Kolkata Campus

Southend Conclave, $4^{\text {th }}$ Floor, 1582 Rajdanga Main Road, Kolkata 700107, India

Tel: 91-33-2441-4542Ｅ-mail: sdutta@bitmesra.ac.in
\end{abstract}

Received: November 25, 2016 Accepted: December 16, 2016

doi:10.5296/ber.v6i2.10560 URL: http://dx.doi.org/10.5296/ber.v6i2.10560

\begin{abstract}
The wide use of ICT applications has opened enormous opportunities for large, medium and even small organizations. This study aims to investigate the extent of adoption of e-commerce applications by the women owned SMEs in India, with special focus on behavioral factors which influence them to do so. The Unified Theory of Acceptance and Use of Technology (UTAUT) model was utilized to determine the strength of the constructs in influencing e-commerce adoption amongst women entrepreneurs. Using a structured questionnaire, responses were solicited via a field survey amongst 144 women entrepreneurs in two districts of Kolkata and 24 Parganas (South) in the State of West Bengal, India. The results show that three constructs, namely, performance expectancy, effort expectancy and social influence significantly affect the behavioral intention of these women entrepreneurs to use e-commerce. Experience and voluntariness to use are the moderators significantly correlated with effort expectancy, facilitating conditions and social influence. Moreover, it has been revealed that facilitating conditions and the behavioral intention positively influence their usage behavior.
\end{abstract}

Keywords: UTAUT, E-commerce, Women entrepreneurs, Technology acceptance 


\section{Introduction}

Information and Communication Technology (ICT) is increasingly being incorporated in businesses of all sizes. ICT applications enhance the competitive edge of the firms by attributing to better efficiency and improved productivity culminating to higher profitability. The Internet has emerged to be the game changer for the businesses across the world. One ICT application which is widely being utilized by firms, irrespective of size, is e-Commerce. E-commerce (electronic commerce) is the buying and selling of goods and services, or the transmitting of funds or data, over an electronic network, mainly the Internet. These transactions are in the nature of either business - to - business (B2B), business -to - consumer (B2C), consumer-to-consumer (C2C) or consumer-to-business (C2B). In India, e-commerce has emerged as viable business tool due to the rapidly growing Internet base in the country with India being the largest country in terms of new Internet user addition, adding 63 million new users and having more than 232 million internet users (Vikas, 2015). Growing popularity of mobile commerce has generated $41 \%$ of the total e-commerce sales from the mobile platform in 2014 and has led to escalating usage of mobile wallets (Vikas, 2015). In India, $43 \%$ of SMEs participate in online sales, although, they may or may not host their own online portal. Web-enabled SMEs, in general, make higher profits, have improved customer reach and increased employment opportunities.

Inspite of rapid growth of Internet users, women are still facing challenges that are creating obstacles in ICT implementation. Issues related to the gender digital divide have been prominent discussions amongst the researchers in recent times. One of the major concerns for women entrepreneurs intending to implement ICT applications in their businesses is the availability of suitable infrastructure. Problems like inadequate supply of electricity and network coverage are the reasons for slower adoption (Vossenberg, 2013). Women are often discouraged, both at the family and societal levels, in their ICT enabled entrepreneurial efforts (Badran, 2014). The high costs of ICT tool is another major barrier for women entrepreneurs in implementing ICT (Mugoshi, 2013). Several development agencies such as World Bank, USAID and the Canadian International Development Research Centre (IDRC) have increased their funding in the development of ICT projects that are especially aimed to empower women entrepreneurs (Maier and Reichert, 2008).

SMEs in every nation play a vital role as engines of growth by contributing to innovation, job creation, export earnings, social upliftment and poverty reduction. SMEs in India contribute to 17 per cent to the country's GDP, 45 percent of the industrial output, 40 percent of exports and 42 million in employment (SME Chamber of India). In this country, women managed SMEs are definitely showing an emerging and positive trend since 1985. Studies in India have substantiated that women business owners in India are now confident and optimistic about business growth (Dell Women's Global Entrepreneurship Study, 2012). Women entrepreneurs are proactive about using technology like e-commerce in their business operations. E-commerce has the potential to provide Indian business women a flexible, accessible and cost effective platform for marketing their products across the globe. Nair (2015) reported that women have started adopting e-commerce in their businesses even at an early age of 25 years. Though most of the women entrepreneurs hail from the tier I cities, 
there has been a significant rise recently in the number of women traders from tier II and tier III cities. e-Bay, the renowned e-commerce company is promoting e commerce amongst women entrepreneurs in India and has registered more than 5000 women sellers (Nair, 2015). e-Bay has also been organizing training workshops in order to equip the women entrepreneurs with the necessary skills for smooth functioning of their online businesses. Indian women entrepreneurs registered on Alibaba.com manage a varied set of industries ranging from hair and beauty to gems and jewellery, machinery to food processing.

Women owned SMEs encounter many challenges that finally impact the implementation of the e-commerce based business model. Women entrepreneurs are fear of security of payments and privacy of online transactions. The challenges arise due to poor education background and inadequate training along with dearth of financial and social support. All these barriers lead to low rate of technology adoption by the women entrepreneurs as compared to their male counterparts (OECD, 2004).

In this paper, we are going to explore to what extent women entrepreneurs in a metro city like Kolkata along with those in suburban areas intend to adopt new technology like e commerce. The behavioral intention of these women will be examined by using the UTAUT Model of technology acceptance.

\section{Theoretical Model}

This study investigates the relationship between the moderators (like age, experience and voluntariness) and the determinants that affect the acceptance and usage of e commerce technology amongst the women entrepreneurs in West Bengal, India by implementing Unified Theory of Acceptance and Use of Technology (UTAUT). It also explains the extent of variation in the behavioral intention of these women to adopt e commerce.

\subsection{Model}

Various theoretical models have been established to study the behavioral intentions to adopt technologies. Such models are the Theory of Reasoned Action (TRA) (Fishbein and Ajzen, 1975), the Theory of Planned Behavior (TPB) (Ajzen, 1991), the Technology Acceptance Model (TAM) (Davis, 1989), the Combined -TAM-TPB model (C-TAM-TPB) (Taylor and Todd, 1995), the Motivational Model (MM) (Davis et al., 1992), the Innovation Diffusion Theory (IDT) (Rogers, 1995), Model of PC Utilization (MPCU) (Thompson et al., 1991), Social Cognitive Theory (SCT) (Bandura,1988). Venkatesh et al. (2003) combined these 8 models to form Unified Theory of Adoption and Use of Technology (UTAUT) to study the behavioral intention to use technology. This model consists of four core determinants of intention and usage: Performance Expectancy, Effort Expectancy, Social Influence and Facilitating Conditions and also of four moderators of key relationships: Gender, Age, Experience and Voluntariness. The core determinants are the key factors which influence directly the user's behavioral intention to use new technologies. Moderators are factors, which control the influence of the key factors. (Table 1) provides a summary of the source of each UTAUT construct, with a description and the model from which each construct was derived. (Figure 1) shows the UTAUT Model. 
Table 1. Description of UTAUT variables and models derived from them

\begin{tabular}{|c|c|c|}
\hline Construct & Description of Perception & $\begin{array}{l}\text { Similar Constructs and Corresponding } \\
\text { Models }\end{array}$ \\
\hline \multirow{5}{*}{ Performance Expectancy } & \multirow{5}{*}{$\begin{array}{l}\text { The degree to which an individual } \\
\text { believes that using the system will help } \\
\text { him/her attaining the job performance. }\end{array}$} & $\begin{array}{l}\text { Perceived Usefulness (TAM/TAM2 \& } \\
\text { C-TAM-TPB) }\end{array}$ \\
\hline & & Extrinsic Motivation (MM) \\
\hline & & Relative Advantage (IDT) \\
\hline & & Jobfit (MPCU) \\
\hline & & Outcome expectations (SCT) \\
\hline \multirow{3}{*}{ Effort Expectancy } & \multirow{3}{*}{$\begin{array}{l}\text { The degree of ease associated with the } \\
\text { use of the system }\end{array}$} & Perceived ease of use (TAM/TAM2) \\
\hline & & Complexity (MPCU) \\
\hline & & Ease of Use (IDT) \\
\hline \multirow{3}{*}{ Social Influence } & \multirow{3}{*}{$\begin{array}{l}\text { The degree to which an individual } \\
\text { perceives that important others believe } \\
\text { that he/she should use the new system }\end{array}$} & $\begin{array}{l}\text { Subjective norms (TRA,TAM2, } \\
\text { TPB/DTPB and C-TAM-TPB) }\end{array}$ \\
\hline & & Social Factors (MPCU) \\
\hline & & Image (IDT) \\
\hline \multirow{3}{*}{ Facilitating Conditions } & \multirow{3}{*}{$\begin{array}{l}\text { Refers to consumers' perceptions of the } \\
\text { resources and support available to } \\
\text { perform a behavior }\end{array}$} & $\begin{array}{l}\text { Perceived behavioral } \\
\text { (TPB/DTPB,C-TAM,TPB) }\end{array}$ \\
\hline & & Facilitating Conditions (MPCU) \\
\hline & & Compatibility (IDT) \\
\hline
\end{tabular}




\section{Macrothink}

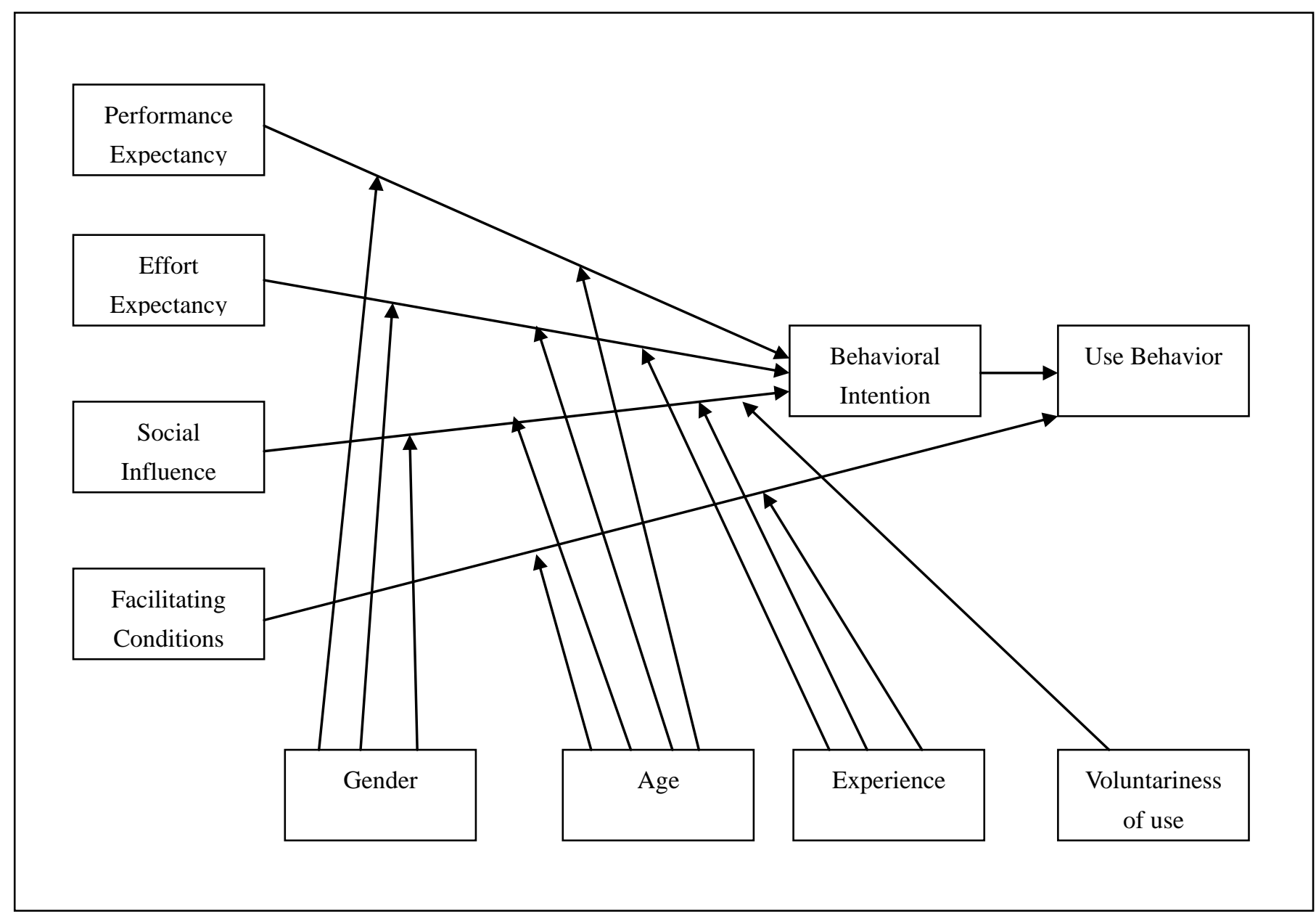

Figure 1. The UTAUT Model, Venkatesh et al. (2003)

Firms irrespective of size have accrued benefits from the adoption of e-commerce in the nature of lower transaction costs, reduction in marketing costs, faster communication between buyers and sellers, increased outreach amongst global customers, minimization of transport obstacles and lower delivery costs (Nejadirani, Behravesh and Rasouli, 2011). Study by Wnyoike, Mukula and Waititu (2012) have highlighted that SMEs that adopt e-commerce perform better than those who do not, due to the catalytic effect of e commerce on business performance. In many developing countries, SMEs are establishing their presence in the global market by exploiting the e commerce applications (Chooprayoon and Fung, 2007). Furthermore, due to extensive use of mobile phones and wide coverage area, mobile commerce is providing good business opportunities to SMEs mainly in the rural areas (Muto and Yamano, 2009).

Inspite of the growing use of ICT applications in SMEs, women entrepreneurs are lagging behind. Dwivedi and Mishra (2013) found that banks are reluctant to provide loans to the women entrepreneurs willing to implement ICT in running their business firms. They are also discouraged socially in their ICT enabled business ventures (Badran, 2014). Mugoshi (2013) highlighted that women entrepreneurs cannot afford to invest in ICT applications due to its high costs of equipments .Linguistic barriers and literacy level are also the major areas of 
challenge (Maier and Reichert, 2007). Alam and Mst. (2007) found that in Malaysia SMEs are unwilling to use ICT because they fail to understand the benefits of using ICT applications.

UTAUT (Unified Theory of Acceptance and Use of Technology) is the recent model which is being widely used to study the factors that influences technology adoption by the firms. In South Africa, Ndayizigamiye (2013) investigated 180 SMEs and concluded that performance expectancy, effort expectancy and social influence of the UTAUT Model are the determinants of their e-commerce adoption. Another study was conducted in Nigeria amongst 150 e-commerce customers across different industries and it was found that performance expectancy, effort expectancy and facilitating conditions have significant relationship on behavioral intention to adopt e-commerce (Stella, Abraham, Juliet and Martins, 2014). Another widely tested model in the context of ICT adoption is the Technology Acceptance Model (TAM). Johar and Awalludin (2011) studied 611 respondents in Malaysia and revealed that perceived usefulness and perceived ease of use are significantly influencing the intention to use e-commerce. Mohabbattalab and Mohabbattalab (2014) studied 106 SMEs in Malaysia and found that perceived usefulness and perceived ease of use are statistically significant to behavioral intention to use cloud computing.

\section{Research Methodology}

To investigate the effect of moderators on determinants and to determine the factors that affect the acceptance and usage of information and communication technologies amongst the women of West Bengal, India by implementing Unified Theory of Acceptance and Use of Technology (UTAUT), the following research methodology was employed in this study:

\subsection{Sample and Data Collection}

The data on women entrepreneurs were collected from the District Industry Centres (DIC) of Kolkata and South 24 Parganas. A sample of 170 women entrepreneurs were randomly selected from the total population of 3,507 women entrepreneurs. They are mainly into micro and small enterprises in West Bengal. Responses were received from 144 entrepreneurs that give the response rate as $85 \%$.

\subsection{Survey Instrument}

A structured questionnaire was formulated to capture the relevant information. Interview method was used to collect data regarding the adoption of e-commerce among the women entrepreneurs. All the variables were measured using 5 point Likert Scale ranging from Strongly Agree to Strongly Disagree. There were 3 sections in the questionnaire: section 1 captured data on demographic profile of the respondents, Section 2 captured the level of e-commerce adoption and Section 3captured the details on the UTAUT Model. A list of validated items for each of the construct is provided in (Table 2). 
Table 2. Questionnaire Items

\begin{tabular}{|c|c|c|}
\hline Constructs & Question description & References \\
\hline \multirow{4}{*}{$\mathrm{PE}$} & PE 1: I would find e-commerce useful in my job & \multirow{4}{*}{$\begin{array}{l}\text { Venkatesh, Morris, Davis } \\
\text { and Davis (2003) }\end{array}$} \\
\hline & $\begin{array}{l}\text { PE } 2 \text { : Using e-commerce in my job would increase my } \\
\text { productivity }\end{array}$ & \\
\hline & $\begin{array}{l}\text { PE 3: Using e-commerce enables me to accomplish tasks } \\
\text { more quickly }\end{array}$ & \\
\hline & PE 4: Using e-commerce would make it easier to do my job & \\
\hline \multirow{4}{*}{$\mathrm{EE}$} & EE 1: E-commerce is clear and understandable & \multirow{4}{*}{ Venkatesh et al. (2003) } \\
\hline & EE 2: E-commerce makes me skillful at using the system & \\
\hline & EE 3: E-commerce is easy to use & \\
\hline & EE4 : Learning to operate the e-commerce is easy for me & \\
\hline \multirow{2}{*}{ SI } & $\begin{array}{l}\text { SI } 1 \text { : People who influence my behavior think that I should } \\
\text { use e-commerce }\end{array}$ & \multirow{2}{*}{ Venkatesh et al. (2003) } \\
\hline & $\begin{array}{l}\text { SI 2: People who are important to me think that I should use } \\
\text { e-commerce }\end{array}$ & \\
\hline \multirow{2}{*}{$\mathrm{FC}$} & FC 1: I have the resources necessary to use e-commerce & \multirow{2}{*}{ Venkatesh et al. (2003) } \\
\hline & FC2: I have the knowledge necessary to use e-commerce & \\
\hline \multirow{3}{*}{ BI } & BI 1: I intend to use e-commerce in the next 12 months & \multirow{3}{*}{ Venkatesh et al. (2003) } \\
\hline & BI 2: I predict I would use e-commerce in the next 12 months & \\
\hline & BI 3: I plan to use e-commerce in the next 12 months & \\
\hline \multirow{3}{*}{ UB } & UB 1: I frequently use e-commerce applications & \multirow{3}{*}{ Venkatesh et al. (2003) } \\
\hline & UB 2: I use e-commerce applications on regular basis & \\
\hline & $\begin{array}{l}\text { UB 3: Most of my transactions are done through e-commerce } \\
\text { applications }\end{array}$ & \\
\hline
\end{tabular}

\section{Research Hypotheses}

According to the UTAUT Model, four factors influence the usage of new technology which is e-commerce in our study. The four factors are performance expectancy, effort expectancy, social influence and facilitating conditions. We have also investigated the moderating effect of age, voluntariness of use and experience in this study. The hypotheses were:

- Hypothesis 1: Performance Expectancy positively affects user's intention to use e-commerce

- Hypothesis 2: Effort Expectancy positively affects user's intention to use e-commerce

- Hypothesis 3: Social Influence positively affects user's intention to use e-commerce

- Hypothesis 4: Facilitating Conditions positively affects use behavior

- Hypothesis 5: Behavioral Intention positively affects use behavior

\section{Research Findings}

\subsection{Demographic and SME Profile}

The sample is predominantly comprised of mid-aged women ending in the age group of 


\section{Macrothink}

Business and Economic Research

ISSN 2162-4860

2016, Vol. 6, No. 2

31-50 i.e 79\%. Most of them are college graduates. It has been observed that $88 \%$ of them are engaged into Manufacturing sector while $13 \%$ are engaged into Service sector. Proprietorship is the main form of ownership (74\%). Table 3 gives the demographic profiles of the respondents.

Table 3. Demographic Profiles of the Respondents

\begin{tabular}{|l|c|c|}
\hline Characteristics & Number & Percentage \\
\hline Age & & \\
\hline $25-30$ & 17 & $12 \%$ \\
\hline $31-40$ & 64 & $44 \%$ \\
\hline $41-50$ & 50 & $35 \%$ \\
\hline $51-60$ & 10 & $7 \%$ \\
\hline More than 60 & 3 & $2 \%$ \\
\hline Education & & \\
\hline Below School level & 1 & $1 \%$ \\
\hline School Passout & 28 & $19 \%$ \\
\hline Graduate & 96 & $67 \%$ \\
\hline Post Graduate & 19 & $13 \%$ \\
\hline Sector & & \\
\hline Manufacturing & 126 & $88 \%$ \\
\hline Service & 18 & $12 \%$ \\
\hline Type of ownership & & \\
\hline Proprietorship & 106 & $74 \%$ \\
\hline Partnership & 32 & $22 \%$ \\
\hline Public Ltd & 1 & $1 \%$ \\
\hline Pvt Ltd & 5 & $3 \%$ \\
\hline Nature of Business & & \\
\hline Beauty \& Cosmetics & 7 & $5 \%$ \\
\hline Electrical Goods & 15 & $10 \%$ \\
\hline Food Products \& Services & 6 & $4 \%$ \\
\hline Furniture & 8 & $6 \%$ \\
\hline Garments & 36 & $25 \%$ \\
\hline Handicrafts & 29 & $20 \%$ \\
\hline Leather Goods & 11 & $8 \%$ \\
\hline Printing Photography & 4 & $5 \%$ \\
\hline Travel \& Advertising & 21 & $15 \%$ \\
\hline Others & & \\
\hline
\end{tabular}

\subsection{Level of Adoption/Use}

Mutua, Oteyo and Njeru (2013) studied 176 SME firms in Kenya and found that e-mail is the most common use of internet followed by browsing and searching. A similar study was conducted by Thi and Ang (2008) in Malaysia amongst 187 SMEs and the result showed that 


\section{Macrothink}

Business and Economic Research

ISSN 2162-4860

2016, Vol. 6, No. 2

e-mail is the most widely adopted application, followed by online brochure and online catalogue. In Egypt, 150 SMEs were being studied on e-commerce adoption and revealed that most of the enterprises implemented electronic advertising in their firms (Zaied, 2012). Figure 2 illustrates the nature of e-commerce applications adopted by the women entrepreneurs in their business operations. The result shows all women are using emails (100\%), $74 \%$ are engaging in online delivery, $74 \%$ are making use of billing and payment facility and only $53 \%$ are utilizing e-commerce for customer service.

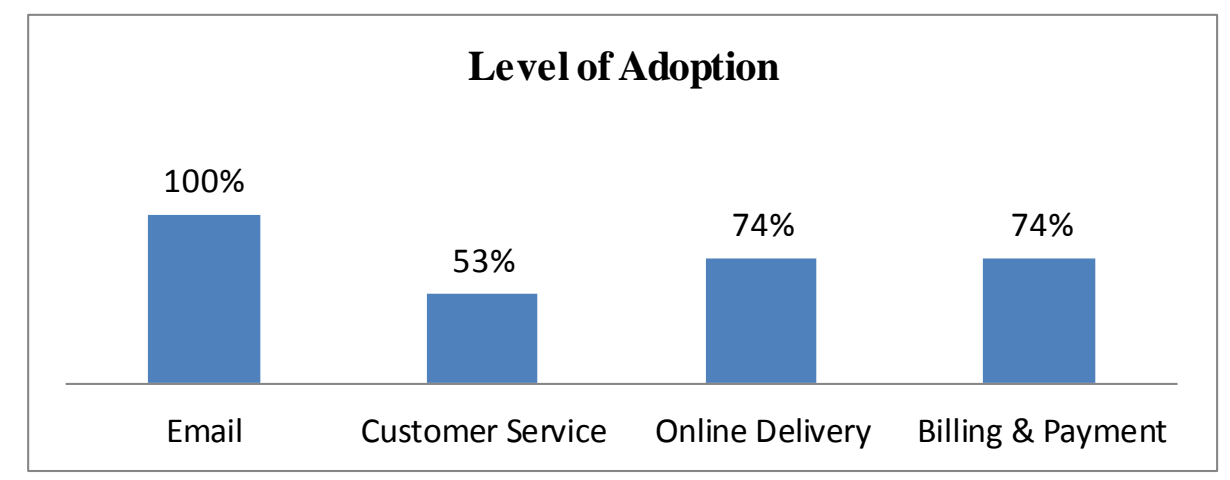

Figure 2. Level of Adoption of e-commerce applications

\subsection{Reliability Analysis}

Cronbach's Alpha test was conducted to test the reliability of the determinants. A value higher than 0.70 is acceptable. In this test, all the variables have value more than 0.70 ,demonstrating good reliability.

Table 4. Reliability Test

\begin{tabular}{|l|c|}
\hline Variables & Cronbach's alpha \\
\hline Performance Expectancy & 0.978 \\
\hline Effort Expectancy & 0.972 \\
\hline Social Influence & 0.959 \\
\hline Facilitating Conditions & 0.96 \\
\hline Behavioral Intention & 0.969 \\
\hline Use Behavior & 0.973 \\
\hline
\end{tabular}

\subsection{Correlation Analysis}

Correlation analysis was used to determine the strength of the correlation between each determinant and the behavioral intention to use e-commerce by the women entrepreneurs. Also, it helped to analyze how strongly each of the moderators i.e, age, experience and voluntariness to use is associated with behavioral intention and use behavior. Table 4 depicts that age is not considered as moderator for performance expectancy, effort expectancy, social influence and facilitating conditions. Experience is a moderator for effort expectancy, social influence and facilitating conditions. This concludes that with increase in experience, the women entrepreneurs find more ease in managing e-commerce applications and thus effort expectancy increases. Women having limited experience on e-commerce services are not 
strongly influenced by peer influence. Social influences are moderately related to voluntariness to use e-commerce applications. With increase facilitating conditions, women entrepreneurs tend to use e-commerce applications for a longer period of time.

Table 5. Correlation Analysis

\begin{tabular}{|l|c|c|c|}
\hline Corr & Age & Experience & Voluntariness to use \\
\hline PE & -0.028 & - & - \\
\hline EE & -0.022 & $.831^{* *}$ & - \\
\hline SI & -0.029 & $.471^{* *}$ & $.677^{* *}$ \\
\hline FC & -0.024 & $.830^{* *}$ & - \\
\hline
\end{tabular}

**.Correlation is significant at 0.01 level

\subsection{Regression Analysis}

This analysis is to examine the variation in the behavioral intention to use e-commerce caused by factors such as performance expectancy, effort expectancy, facilitating condition and social influence. The Model 1 shows that performance expectancy, effort expectancy and social influence significantly affect behavioral intention to use e-commerce by the women entrepreneurs (Table $6 \mathrm{a}$ and $6 \mathrm{~b}$ ). Here, $\mathrm{R}$ square is .833 indicating that $83.3 \%$ variation in the behavioral intention to use e-commerce can be explained by the independent variables. Performance expectancy is having largest $\beta$ value which means that it is more influencing behavioral intention as compared to effort expectancy and social influence. Thus, the whole model is statistically significant.

Table 6a ANOVA ${ }^{\mathrm{a}}$

\begin{tabular}{|c|c|c|c|c|c|c|}
\hline \multicolumn{2}{|c|}{ Model 1} & Sum of Squares & df & Mean Square & $\mathrm{F}$ & Sig. \\
\hline \multirow[b]{3}{*}{1} & Regression & 274.755 & 3 & 91.585 & 232.795 & $.000^{\mathrm{b}}$ \\
\hline & Residual & 55.078 & 140 & 0.393 & & \\
\hline & Total & 329.833 & 143 & & & \\
\hline \multicolumn{7}{|c|}{ a. Dependent Variable: BI } \\
\hline \multicolumn{7}{|c|}{ b. Predictors: (Constant), SI, EE, PE } \\
\hline
\end{tabular}

Table 6b. Regression of Constructs to Behavioral Intention to Use

\begin{tabular}{|l|c|c|c|}
\hline & $\beta$ & t-value & Sig. \\
\hline $\mathrm{PE}$ & 0.58 & 7.714 & 0 \\
\hline $\mathrm{EE}$ & 0.2 & 2.975 & 0.003 \\
\hline $\mathrm{SI}$ & 0.178 & 2.725 & 0.007 \\
\hline $\mathrm{R}^{2}$ & \multicolumn{3}{|c|}{0.833} \\
\hline Adjusted $\mathrm{R}^{2}$ & \multicolumn{3}{|c|}{0.829} \\
\hline
\end{tabular}

The Model 2 evaluates the effect of facilitating conditions and behavioral intention towards usage behavior of e-commerce applications. The results show that both facilitating conditions and behavioral intention significantly influence usage behavior (Table 7a and7b). Here, $\mathrm{R}$ square is .659 indicating that $65.9 \%$ variation in the usage behavior of e-commerce can be 
explained by the independent variables. Again, behavioral intention is having largest $\beta$ value which means that it is more influencing usage behavior as compared to facilitating conditions. The entire model is statistically significant.

Table 7a ANOVA ${ }^{\mathrm{a}}$

\begin{tabular}{|c|c|c|c|c|c|c|}
\hline \multicolumn{2}{|c|}{ Model 2} & $\begin{array}{l}\text { Sum of } \\
\text { Squares }\end{array}$ & df & $\begin{array}{l}\text { Mean } \\
\text { Square }\end{array}$ & $\mathrm{F}$ & Sig. \\
\hline & Regression & 218.039 & 2 & 109.019 & 136.222 & $.000^{\mathrm{b}}$ \\
\hline & Residual & 112.843 & 141 & 0.8 & & \\
\hline 1 & Total & 330.882 & 143 & & & \\
\hline \multicolumn{7}{|c|}{ a. Dependent Variable: UB } \\
\hline \multicolumn{7}{|c|}{ b. Predictors: (Constant), BI, FC } \\
\hline
\end{tabular}

Table 7b. Regression of FC and BI to Use Behavior

\begin{tabular}{|c|c|c|c|}
\hline & $\beta$ & t-value & Sig. \\
\hline $\mathrm{FC}$ & 0.382 & 4.569 & 0 \\
\hline $\mathrm{BI}$ & 0.471 & 5.632 & 0 \\
\hline \multicolumn{2}{|c|}{$\mathrm{R}^{2}$} & \multicolumn{2}{|c|}{0.659} \\
\hline \multicolumn{2}{|c|}{ Adjusted $\mathrm{R}^{2}$} & \multicolumn{2}{|c|}{0.654} \\
\hline
\end{tabular}

\section{Confirmation of Hypotheses}

\subsection{The Influence of Women Entrepreneurs' Performance Expectancy on Intention to Use E-Commerce}

The regression results show that it is supported as performance expectancy positively affects women entrepreneurs' intentions to use e-commerce in running their businesses $(\beta=.580, p<.001)$. This indicates that when women entrepreneurs expect that utilising e-commerce would increase their performance, their intention to use is strengthened.

\subsection{The Influence of Women Entrepreneurs' Effort Expectancy on Intention to Use E-Commerce}

The result in Table $5 \mathrm{~b}$ show that effort expectancy positively affects women entrepreneurs' intentions to use e-commerce in running their businesses $(\beta=.200, \mathrm{p}<.010)$. Therefore, $\mathrm{H} 2$ is supported. If women entrepreneurs perceive that e-commerce applications are easy to use, their intention to adopt it is increased.

\subsection{The Influence of Women Entrepreneurs 'Social Influence on Intention to Use E-Commerce}

H3 is supported as it is evident that women entrepreneurs intention to use e-commerce applications is positively affected by the support and suggestion of influential persons/peers $(\beta=.178, p<.010)$.

\subsection{The Influence of Women Entrepreneurs 'Facilitating Conditions on Use Behavior}

The result in Table $6 \mathrm{~b}$ showed that facilitating conditions positively influence usage behavior 
of e-commerce $(\beta=.382, \mathrm{p}<.001)$. Thus, $\mathrm{H} 4$ is supported. This shows that if infrastructural facilities are properly available, more frequently use of e-commerce applications can be ensured.

\subsection{The Influence of Women Entrepreneurs' Intention to Use E-Commerce on Use Behavior}

Since H5 is supported, it is evident that the behavioral intention to use e-commerce is significantly translates into actual usage behavior $(\beta=.471, \mathrm{p}<.001)$.

\section{Conclusion}

The results of this study supported the UTAUT Model in explaining the effect of constructs on behavioral intention to use e-commerce. The influence of performance expectancy on respondents' behavioral intention was significant. The intention to use e-commerce by the women entrepreneurs increase if using the applications would increase their productivity. The sampled women entrepreneurs have realized that e-commerce applications can enhance the productivity and profitability of their businesses and therefore, it is acting as a positive influence on their intention to use e-commerce. The statistically significant influence of effort expectancy suggests that the respondents will be eager to use e-commerce applications if they are easy to use. Peer influence exerts a statistically significant influence on women entrepeneurs' intention to use e-commerce. Both behavioral intention and facilitating conditions were found to be significant for women entrepreneurs' use behavior of e-commerce applications. This suggests that necessary resources and infrastructure should be provided to encourage the women entrepreneurs to use e-commerce applications.

For an effective adoption of e-commerce applications by the women entrepreneurs, widespread and attractive awareness campaigns and training programmes should be conducted, targeting the potential users so that they can be informed about benefits that can be reaped by implementing the services. This study is limited to Kolkata and South 24 Parganas of West Bengal. It is expected better results will be generated if the study is extended over a larger territory. Moreover, a cross country comparative study may also be undertaken to analyze the behavioral intention of entrepreneurs to use e-commerce in their business firms.

\section{References}

Ajzen, I. (1991). The theory of planned behavior. Orgnizational Behavior and Human Decision Processes, 50, 179-211. http://doi.org/10.1016/0749-5978(91)90020-T

Alam, S. S., \& Mst. N. A. (2007). ICT Adoption in Malaysian SMEs from Services Sectors: Preliminary Findings. Journal of Internet Banking and Commerce, 12(3), 1-11.

Awais, M., \& Samin, T. (2012). Advanced SWOT Analysis of E-Commerce. International Journal of Computer Sciences Issues, 9(2), 569-574.

Badran, M. F. B. (2014). Working Paper No. 2014/12 Access and use of ICT in female owned SMEs in selected Arab countries and Brazil: A comparative study. Maastricht School of Management. 


\section{Mll Macrothink}

Business and Economic Research ISSN 2162-4860 2016, Vol. 6, No. 2

Bandura, A. (1988).Organizational Application of Social Cognitive Theory. Australian Journal of Management, 13(2), 275-302. https://doi.org/10.1177/031289628801300210

Chooprayoon, V., \& Fung, C. (2007). An empirical study on the influencing factors on the adoption and use of e-commerce by Thailand SMEs.The Sixth Wuhan International Conference on E-Business, 141-149.

Retrieved from http://researchrepository.murdoch.edu.au/913/

Davis, F. D. (1989). Perceived Usefulness, Perceived Ease of Use, and User Acceptance of Information Technology.MIS Quarterly, 13(3), 319-339. https://doi.org/10.2307/249008

Davis, F. D., Bagozzi, R. P., \& Warshaw, P. R. (1992). Extrinsic and Intrinsic Motivation to Use Computers in the Workplace. Journal of Applied Social Psychology ,14(22), 1111- 1132. http://doi.org/ 10.1111/j.1559-1816.1992.tb00945.x

Dell Women's Global Entrepreneurship Study:India Key Findings, 2011- 2012.Web.

Esin, R, E., \& Heeks, R. (2015). E-Business Adoption and Use Among African Women-Owned SMEs: An Analytical Study in Nigeria, ICTD 2015 Proceedings of the Seventh International Conference on Information and Communication Technologies and Development. http://doi.org/ 10.1145/2737856.2738015

Fishbein, M., \& I. Ajzen (1975). Belief, Attitude, Intentions and Behaviour: An Introduction to Theory and Research, Reading, MA: Addison-Wesley.

H. Zaied, A. N. (2012). Barriers to E-Commerce Adoption in Egyptian SMEs. International Journal of Information Engineering and Electronic Business, 4(3), 9-18. http://doi.org/10.5815/ijieeb.2012.03.02

Hafkin, N., \& Taggart, N. (2001). Gender, IT and Developing Countries: An Analytic Study; Center for Education Innovations: Washington, DC, USA, 2001.

Jaradat, M. I. R. M., \& Al Rababaa, M. S. (2013). Assessing Key Factor that Influence on the Acceptance of Mobile Commerce Based on Modified UTAUT. International Journal of Business and Management, 8(23), 102-113. http://doi.org/10.5539/ijbm.v8n23p102

Johar, M. G. M., \& Awalluddin, J. A. A. (2011). The Role of Technology Acceptance Model in Explaining Effect on E-Commerce Application System. International Journal of Managing Information Technology (IJMIT), 3(3), 1-14. http://doi.org/10.5121/ijmit.2011.3301

Kapurubandara, M., Arunatileka, S., \& Gnige, A. (2006). Application of Business Strategies for SMEs in Developing Countries.Proceedings, IEEE, International conference on e-technology, e-commerce and e-Service (EEE'04)

Maier, S., \& Reichert, U. N. (2008). ICT-Based Business Initiatives : An Overview of Best Practices in E-Commerce / E-Retailing Projects. MIT Press, 4(2), 43-60.

Mohabbattalab, E., \& Mohabbattalab, B. (2014). Enhancing the competitive nature of Malaysian small and medium enterprises (SMEs) through cloud computing. Global Journal of Engineering, Design and Technology, 3(3), 24-28 


\section{Macrothink}

Business and Economic Research ISSN 2162-4860 2016, Vol. 6, No. 2

Mokaya, S. O. (2012). The Adoption of Information and Communication Technology by Small Enterprises in Thika Municipality, Kenya. International Journal of Business and Social Science, 3(13), 172-177

Mugoshi, C. S. (2013). Factors Influencing Access to Public Pocurement Bidding By Women Entrepreneurs in Kenya. Case of Women-Led SMEs in Nairobi. International Journal of Social Sciences and Entrepreneurship, 1(1),69-85.

Muto, M., \& Yamano, T. (2009).The impact of mobile phone coverage expansion on market participation: Panel data evidence from Uganda.World Development, 37(12), 1887-1896. http//doi.org/10.1016/j.worlddev.2009.05.004

Mutua, J., Oteyo, I. N., \& Njeru, A. W. (2013). The Strategic Value of e-commerce adoption among Small and Mediam Enterprises in Nairobi, Kenya. Proceedings of the 2013 Mechanical Engineering Annual Conference on Sustainable Research and Innovation, 133-138, Nairobi.

Nair, S. (2015). The rising role of India's e-commerce women entrepreneurs. Your Story. Retrieved from https://her.yourstory.com/ecommerce-women-0720

Ndayizigamiye, P. (2013). A UNIFIED APPROACH TOWARDS E-COMMERCE ADOPTION BY SMMES IN SOUTH AFRICA. International Journal of Information Technology and Business Management, 16(1), 92-101.

Nejadirani, F., Behravesh, M., \& Rasouli, R. (2011). Developing countries and electronic commerce the case of SMEs. World Applied Sciences Journal, 15(5), 756-764.ISSN $1818-4952$

OECD (2004). ICT, E-Business and Small and Medium Enterprises. OECD Digital Economy Papers, No. 86, OECD Publishing. http://dx.doi.org/10.1787/232556551425

Rogers, E. (1995). Diffusion of Innovations, Free Press, New York, 1995.

Small and Medium Business Development Chamber of India, Empowering SMEs for Global Competitiveness

Stella, C., Martins, E., \& Academy, N. D. (2014). A Framework for Electronic Commerce Adoption: a Study in Kaduna State, Nigeria. Science World Journal, 9(3), 20-26.ISSN $1597-6343$

Taylor, S., \& Todd, P. (1995). Understanding Information Technology Usage: A Test of Competing Models. Information Systems Research, 6(2), 144-176.

https://doi.org/10.1287/isre.6.2.144

Terry, H. P., Schwartz, D., \& Moore, B. (2014). eCommerce expected to accelerate globally in 2014.Retrieved from http://boletines.prisadigital.com/Global_ecommerce.pdf

Thi, L, S., \& Ang, C. L. (2008). Adoption of E-Commerce Applications by Manufacturing SMEs in Malaysia: An Empirical Investigation. e-Case, At Bangkok, Volume 1. 


\section{Macrothink}

Business and Economic Research

ISSN 2162-4860 2016, Vol. 6, No. 2

Thompson, R. L., Higgins, C. A., \& Howell, J. M.(2008).Personal Computing: Toward a Conceptual Model of Utilization.MIS Quarterly,15(1), 124-143

Venkatesh, V., M. Morris, G. Davis, \& F. Davis. (2003). User acceptance of information technology: toward a unified view. MIS Quarterly, 27(3), 425-478.

http://doi.org/10.2307/30036540

Vikas, S. N. (2015). 41\% of India E-commerce sales is from Mobile: Meeker's 2015 Internet Trends, Economic Times.

Vossenberg, S. (2013). Working Paper No. 2013 / 08 Women Entrepreneurship Promotion in Developing Countries: What explains the gender gap in entrepreneurship and how to close it? Maastricht School of Management, 1-27.

Wnyoike, D., Mukulu,E., \& Waititu, A. (2012). ICT attributes as determinants of e-commerce adoption by formal small enterprises in urban Kenya.International Journal of Business and Social Sciences, 3(7).

\section{Copyright Disclaimer}

Copyright for this article is retained by the author(s), with first publication rights granted to the journal.

This is an open-access article distributed under the terms and conditions of the Creative Commons Attribution license (http://creativecommons.org/licenses/by/3.0/). 